\title{
The Effect of Psychological Contracts: Transactional, Relational, Balance on Organizational Citizenship Behaviors University Staff in Indonesia and Malaysia
}

\author{
Retno Dwiyanti ${ }^{1}$, Pambudi Rahardjo ${ }^{2}$, Imam Faisal Hamzah ${ }^{3}$, Siti Aisyah binti Panatik ${ }^{4}$ \\ ${ }^{123}$ Universitas Muhammadiyah Purwokerto, Indonesia \\ ${ }^{4}$ Universiti Teknologi Malaysia
}

\begin{abstract}
Organization Citizenship Behavior is an extra-role individual behavior that is discretionary which is not directly recognized by the formal reward system and will jointly encourage organizational functions. Psychological contracts and their fulfillment are linked to employee responses consisting of intra-role and extra-role performance. The purpose of this study was to determine the effect of the transactional contract, relational contract, and balance contract on organizational citizenship behavior. The sample in this study was 313 university staff in Indonesia and universities in Malaysia. Data collection used a psychological contract scale and a scale of organizational citizenship behavior. The result of this study is that there is a significant influence between the relational contract and balance contract on organizational citizenship behavior. Meanwhile, there is no effect of the transactional contract on organizational citizenship behavior.
\end{abstract}

Key words : Psychological contract, transactional, relational, balance, organizational citizenship behavior

\section{Introduction}

Academic staff is a fundamental human resource in an education system in higher education who has a very important role and responsibility in realizing human quality. Academic staff is employees at universities, who are required to perform optimally so as to create a professional and high-quality performance. This situation will be created if it is based on the sincere behavior of the employees at work. Employees are required to work according to the standards set by the organization. This means that to achieve the highest performance, employees are required to behave in accordance with organizational expectations. Therefore, there is a formal description of the behavior to be performed (intra-role behavior). In fact, many behaviors are not formally explained in terms of what employees do, for example helping colleagues solve serious problems, attending company meetings, not complaining much and working a lot, and so on. This behavior is referred to as extra-role behavior. If the leader evaluates the employee's performance, then not only the intra-role behavior is evaluated but the extra-role behavior becomes part of the evaluation because the extrarole behavior has the same important contribution as the intra-role behavior (Hui, et al., 2000). One of the competencies that employees must have is extra-role behavior, namely Organization Citizenship Behavior (OCB). Organization Citizenship Behavior (OCB) is individual discretionary behavior that is not directly recognized by the formal reward system and together will encourage organizational functions to be more effective. Behavior that goes beyond their general job duties is referred to as extra-role behavior. This behavior is highly valued when performed by employees, although it is not formally described because it will increase effectiveness and performance.

Robinson (1996) states that psychological contracts and their fulfillment are associated with employee responses consisting of intra-role and extra-role performance. A psychological contract (PC) is an employee cognitive evaluation of the extent to which the fulfillment of implicitly promised obligations in the employment relationship (Rousseau 1995). The psychological contract consists of three forms, namely Transactional, which refers to a short-term exchange related to specific contributions and benefits that are highly economic or monetary focused; Relational refers to a long-term arrangement without the possibility 
of specific performance rewards. A relational contract involves satisfying relationships with each other by means of an open-end agreement covering socio-emotional; and Balance, which is a combination that focuses on open and satisfying final relationships, with a transactional plan in the form of possible specific performance rewards (Rousseau and Guillermo, 2004).

The results of research from Anjar \& Dwiyanti (2016) found that contract employees have psychological contracts in the transactional category, namely working based on economic factors. According to Armstrong, a psychological contract as an unwritten informal contract consists of the expectations (expectations) of the employees and their superiors regarding a reciprocal work relationship. That is, a psychological contract arises when employees believe that the company's obligations to employees will be proportional to the obligations that employees give to the company, for example, employees believe that the company will provide job security and opportunities for promotion/promotion, and are committed to the company (Anoraga, 2009).

Furthermore, the results of research conducted by Oktaviani and Fauziah (2017) show that there is a positive relationship between psychological contracts and Organizational Citizenship Behavior that occurs in employees. The more positive the psychological contract the individual has, the higher the employee organizational citizenship behavior, whereas, if the individual with a negative psychological contract, the lower the employee organizational citizenship behavior.

Based on these descriptions, this study aims to determine the effect of transactional contracts, relational contracts, and balance contracts on organizational citizenship behavior.

\section{Method}

The approach in this research uses quantitative methods. The subjects of this study were 313 university staff in Indonesia and Malaysia. The data collection method used was a psychological contract scale and a scale of organizational citizenship behavior. The Psychological Contract Scale from Rousseau (2004) developed by (Dwiyanti, 2006) consists of three forms, namely Transactional, Relational, and Balance. The organizational citizenship behavior instrument used in this study was a modification of the instrument developed by Sharma and Sangeeta (2014). The measurement scale contains four elements, namely altruism, organizational compliance, sportsmanship, and loyalty. Subjects responded to all items based on a 5-point Likert scale $(1=$ strongly disagree to $5=$ strongly agree $)$. In this study, the psychological contract scale has a reliability of 0.796 , and the OCB scale has a reliability of 0.952 .

The data analysis used was multiple regression analysis, to determine the effect of transactional contracts, relational contracts, and balance contracts on organizational citizenship behavior.

\section{Results and Discussion}

Based on demographic data, the characteristics of the respondents from the 313 participating subjects are listed in table 1 below:

Table 1. Characteristics of respondents

\begin{tabular}{|l|c|c|}
\hline & Frequency & Percent \\
\hline Gender : & 152 & $48.6 \%$ \\
Men & 161 & $51.4 \%$ \\
Women & $\mathbf{3 1 3}$ & $\mathbf{1 0 0} \%$ \\
\hline Total & 188 & \\
\hline Nationality : & 125 & $60.1 \%$ \\
Indonesia & $\mathbf{3 1 3}$ & $\mathbf{1 0 0} \%$ \\
\hline Malaysia & & \\
\hline Total & 186 & $59.4 \%$ \\
\hline Job Status : & 127 & $40.6 \%$ \\
Lecturer & $\mathbf{3 1 3}$ & $\mathbf{1 0 0} \%$ \\
\hline Staff & & \\
\hline Total &
\end{tabular}


Based on demographic data, the characteristics of respondents from the 313 subjects who participated, $51.4 \%$ were women, and $48.6 \%$ were man. Respondents who are Indonesian nationals are $60.1 \%$, and Malays are $39.9 \%$, work status as lecturers is $59.4 \%$ and staff is $40.6 \%$.

To determine the effect of transactional contracts, relational contracts, and balance contracts on organizational citizenship behavior, the research data were analyzed using multiple regression analysis. The following is the research scheme analyzed:

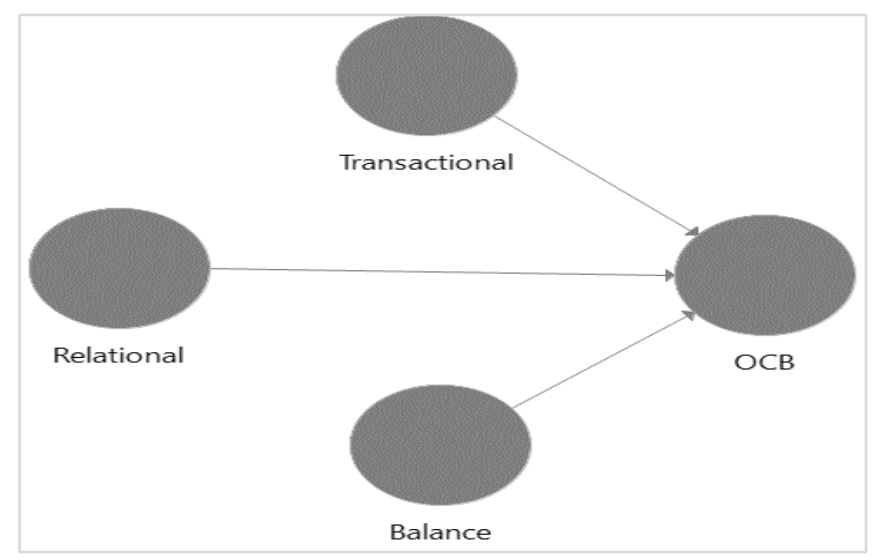

Figure 1. Research Schemes

The results of the analysis of the effect of transactional contracts, relational contracts, and balance contracts on organizational citizenship behavior are as follows:

Table 2. Regression Analysis Results

\begin{tabular}{|l|c|c|c|c|c|l|}
\hline \multicolumn{1}{|c|}{ Variable } & F & t & r & Rsquare & P & \multicolumn{1}{c|}{ Ket } \\
\hline TC $>$ OCB & 1.163 & 1.078 & 0.061 & 0.004 & 0.282 & Not Signifikan \\
\hline RC $>$ OCB & 35.098 & 5.924 & 0.317 & 0.101 & 0.000 & Signifikan \\
\hline BC $>$ OCB & 19.867 & 4.457 & 0.244 & 0.060 & 0.000 & Signifikan \\
\hline $\begin{array}{c}\text { TC,RC,BC } \\
\text { OCB }\end{array}$ & 11.635 & 12.841 & 0.317 & 0.101 & 0.000 & Signifikan \\
\hline
\end{tabular}

Based on the results of data analysis in Table 2, shows that there is no significant effect of transactional contracts on organizational citizenship behavior $(\mathrm{F}=1.163, \mathrm{t}=1.078, \mathrm{P}=0.282)$. Transactional psychological contracts refer to a short-term exchange of specific contributions and benefits that are highly economic or monetary focused. A transactional contract is a form of psychological contract which some employees perceive to be the lowest compared to other forms of contract (relational contract and balanced contract). Transactional contracts limit employee involvement and opportunities for training and development. Employees in performing tasks required by the company only identify that employees perform tasks according to the agreement during recruitment and employees do work only that is paid for by the company. The results show that there is no relationship between transactional contracts and organizational citizenship behavior, so it can be concluded that employee organizational citizenship behavior is not influenced by employee involvement and limited opportunities.

The second result shows that there is a significant effect between relational contracts and organizational citizenship behavior $(\mathrm{F}=35.098, \mathrm{t}=5.924, \mathrm{p}=0.000)$. Relational contracts involve socio-emotional factors, such as trust, security, and loyalty. Each party hopes to have a reciprocal relationship. Psychological contracts involve socio-emotional considerations, trust, and identification and are not easy to remedy in the event of a breach of contract. The psychological contract includes a deep emotional component to the experience of inequality in the relationship (Rousseau, 1989). Hui and Rousseau (2004) in their research 
found that outside of transactional contracts, relational contracts have a relatively strong influence on citizenship behavior.

The third result shows that there is a significant effect between the psychological balance contract on organizational citizenship behavior $(\mathrm{F}=19,867, \mathrm{t}=4.457, \mathrm{p}=0.000)$. Balanced contracts are dynamic and open (open-ended) that focus on the economic success of the company and the opportunity for employees to develop careers. Both employees and companies contribute to each other in learning and development. A balanced contract is a form of psychological contract which some employees perceive to be the highest compared to other forms of contract (transactional contract and relational contract).

The results also showed that there was a significant influence between transactional contracts, relational contracts, and balance contracts on organizational citizenship behavior $(\mathrm{F}=11,635, \mathrm{t}=12,841, \mathrm{p}=0.000)$. According to Chahar (2019), the components of psychological contracts such as relationship contracts, employer-employee relations, internal progress, emotional affinity, and transactional relationships have different effects on employee organizational citizenship behavior. Robinson \& Morrison (1995) in their study of the relationship between psychological contracts and organizational citizenship behavior examined the relationship between two elements of psychological contracts namely Relational and Transactional Contracts with the five components of organizational citizenship behavior (Altruism, Compliance, Sportsmanship, Politeness, Civic Virtue) and found that organizational citizenship behavior is related to psychological contracts (Low et al, 2016). A similar study conducted by Bang et al. (2016) to examine organizational citizenship behavior among elementary school teachers in Taiwan by combining two heterogeneous perspectives, the integration of factors related to organizational citizenship behavior with the use of both organizational and personal perspectives. It was found that the expected psychological contracts affect organizational citizenship behavior.

\section{Conclusion}

The results of the study can be concluded that the relational contract and balance contract have an influence on organizational citizenship behavior. Meanwhile, transactional contracts have no effect on organizational citizenship behavior. Based on the findings of this study, shows that the relationship involving socioemotional factors, trust, security, and loyalty between leaders and employees can increase organizational citizenship behavior in employees. The limitation of this study is that there are no findings on differences in organizational citizenship behavior between academic staff and administrative staff. The relationship between psychological contracts and dimensions of organizational citizenship behavior has also not been analyzed. Further researchers are expected to research the dimensions of organizational citizenship behavior based on factors that affect organizational citizenship behavior including personality, organizational climate, job insecurity. Organizational citizenship behavior in terms of demographic factors is also important to be studied further.

\section{References}

[1] Anoraga, P. (2009). Psikologi Kerja Cetakan Kelima. Jakarta: PT. Rineka Cipta

[2] Anjar \& Dwiyanti (2016), Kontrak Psikologis Pada Karyawan Kontrak Bagian Marketing Di Pt Nasmoco Purwokerto, Psycho Idea, 14 (2), 17-25.

[3] Bang, N., Kirk, C., Chris, R., \& Arnold, J. (2016). Organizational citizenship behavior, identification, psychological contract and leadership frames: The example of primary school teachers in Taiwan. Asia-Pacific Journal of Business Administration, 8(3), 260-280.

[4] Chahar, B. (2019). Psychological Contract and Organizational Citizenship Behavior: Exploring the Interelatedness through Cross Validation. Academy of Strategic Management Journal. Vol.18 (1).

[5] Dwiyanti, R. (2006). Peran Kecerdasan Emosi Dan Budaya Organisasi Terhadap Kontrak Psikologis.

[6] Hui, C., Lee, C., \& Rousseau, D.M. (2004). Psychological contract and organizational citizenship behavior in China: Investigating generalizability and instrumentality. Journal of Applied Psychology, 89(2), 311-321

[7] Hui, C., Lam, S. S. K., \& Law, K. K. S. (2000). Instrumental Values of Organizational Citizenship Behavior for Promotion: A Instrumental Values of Organizational Citizenship Behavior for Promotion: Journal of Applied Psychology, 85 (5)(November 2014), 822-828. 
https://doi.org/10.1037/0021-9010.85.5.822

[8] Low, C.H., Bordia, P., \& Bordia, S. (2016). What do employees want and why? An exploration of employees' preferred psychological contract elements across career stages. Human Relations, 69(7), 1457-1481.

[9] Oktaviani, A., Fauziah. N. (2017) Hubungan Antarakontrak Psikologis Dengan Organizational Citizenship Behavior Pada Karyawan Kantor Pos Besar Semarang. Jurnal Empati. Vol 6(1), 21-26.

[10] Robinson, S.L., \& Morrison, E.W. (1995). Psychological contracts and OCB: The effect of unfulfilled obligations. Journal of Organizational Behavior, 16, 289.

[11] Rousseau, D.M., \& Guillermo, E.D. 2004. Mutuality and Reciprocity in the Psychological Contract of Employees and Employer. Journal of Applied Psychology. 89. 52 - 72.

[12] Rousseau, D. M. (1995). Psychological Contract in Organizations: Understanding Written and Unwritten Agreements. Thousand Oaks, CA: Sage.

[13] Rousseau, D. M. (1989). Psychological and implied contracts in organizations. Employee Responsibilities and Rights Journal, 2(2), 121-139. https://doi.org/10.1007/BF01384942

[14] Robinson, S. L. (1996). Trust and breach of the psychological contract. Administrative Science Quarterly, 41(4), 574-599. https://doi.org/10.2307/2393868

[15] Sharma, V., \& Sangeeta, J. (2014). A Scale for Measuring Organizational Citizenship Behavior in Manufacturing Sector. Pacific Business Review International, 6(8), 57-62. 